\title{
The effect of animal fat on sheep's diet digestibility, degradability and rumen fermentation process
}

\author{
C. Goulas, G. Zervas and G. Papadopoulos \\ Department of Animal Nutrition, Agricultural University of Athens \\ lera Odos 75, GR - 11855 Athents, Greece
}

(Received 29 December 2000; revised version 18 April 2001; accepted 7 August 2001)

\begin{abstract}
The effect of replacement of maize grain by animal fat in a diet with high level of acid detergent fibre $(27 \%)$ on dict digestibility, rumen fermentation and energy content of the diet was evaluated. Six fistulated wether shecp were used in a $2 \times 2$ Latin square experimental design in three replicates. Forage : concentrate ratio in the diets was $47.7: 52.3$ and animal fat contributed to concentrates by $7 \%$, replacing maize on a weight basis. Digestibility of ether extract was increased $(\mathrm{P}<0.001)$ by $13.1 \%$ for the diet with fat compared to the diet without fat, while digestibility coefficients of the other nutrients were unaffected. The energy content of the diet with fat increased by $3.4 \%(\mathrm{P}<0.05)$. The inclusion of animal fat to sheep diet increased significantly the molar proportion of propionate $(\mathrm{P}<0.05)$ by $10.7 \%$ and the crude protein degradability $(\mathrm{P}<0.001)$ by $4 \%$, and decreased the molar proportion of butyrate by $6.1 \%(\mathrm{P}<0.05)$, the acetate to propionate ratio $(\mathrm{P}<0.01)$ by $13.2 \%$, and the protozoa counts by $32 \%(\mathrm{P}<0.001)$.
\end{abstract}

The results showed that animal fat can replace cereal grains in sheep diets up to the level of $5 \%$ without any problem on rumen fermentation process.

KEY WORDS: animal fat, sheep, digestibility, degradability, fermentation

\section{INTRODUCTION}

Different sources of fat are used in ruminant nutrition to increase diet's energy content, to replace a proportion of cereal grains, or to alter the fatty acids profile of milk fat (Palmquist and Conrad, 1978; Palmquist, 1984; Grummer, 1991). The inclusion of non-protected fat in ruminant dicts can adversely affect the fermentation process in the rumen by causing a reduction on fibre degradability and on 
diet's digestibility. Therefore, the recommended percentage of fat in ruminant diets is 3-5\% (Palmquist and Jenkins, 1980). Fat is not fermented by rumen microorganisms and does not contribute to their growth (Stern et al., 1984). Thus the replacement of highly fermented carbohydrates by fat, can reduce protein synthesis in the rumen (Hvelplund and Madsen, 1990) and consequently animal amino acid requirements may not be met. From the literature it can also be seen that the fibre level of a diet can influence the effect of fat on rumen fermentation process. Thus an increased fibre level may reduce the negative effects of non-protected fat on rumen bacteria, due to the fact that the fatty acids are attached to fibre particles (Palmquist and Conrad, 1978; Palmquist and Jenkins, 1980).

The objective of this work was to study the effects of maize grain replacement by animal fat, when sheep's diet had high ADF content, on diet's digestibility, degradability and rumen fermentation process.

\section{MATERIAL AND METHODS}

Six adults fistulated wethers of the Karagouniko breed, with an average body weight (BW) of $63.3( \pm 3.45) \mathrm{kg}$, were used in a $2 \times 2$ Latin square experimental design in 3 replicates. The first treatment was a diet without fat $(\mathrm{CC})$, while the second one had $7 \%$ animal fat $(\mathrm{FC}$ ) in concentrate (Table 1) in replacement of maize grain on a weight basis. Feed intake was adjusted individually according to sheep BW and consisted of $320 \mathrm{~g}$ lucerne hay $+200 \mathrm{~g}$ wheat straw per day per sheep, and $9 \mathrm{~g}$ concentrates per $\mathrm{kg} \mathrm{BW}$. Thus the sheep were taking on average $520 \mathrm{~g}$ forage $+570 \mathrm{~g}$ concentrate per day with a forage : concentrate ratio of 47.7:52.3. No refusals where left during the whole experimental period, while water was available ad libitum.

TABLE 1

Concentrate composition, $\mathrm{g} \mathrm{kg}^{-1}$

\begin{tabular}{lcc}
\hline Ingredients & $\mathrm{CC}^{1}$ & $\mathrm{FC}^{2}$ \\
\hline Maize & 527 & 452 \\
Wheat middlings & 195 & 195 \\
Sunflower meal & 140 & 140 \\
Soyabcan meal & 90 & 90 \\
Fat & - & 70 \\
$\mathrm{CaCO}$ & 26 & 31 \\
$\mathrm{Calcium}$ phosphate & 12 & 12 \\
NaCl & 3 & 3 \\
Trace mineral and vitamin premix & 7 & 7 \\
\hline
\end{tabular}

' CC: control concentrate

2 FC: concentrate with fat 
The sheep after weighing were put in metabolism cages. Each period lasted 21 days. The first 10 days were used as an adaptation period (pre - experimental), the next 7 days total faecal collection was carried out for digestibility determination, the following 2 days rumen liquid was collected through the fistula at time 0,2 and $4 \mathrm{~h}$ after morning feeding, and the last 2 days dacron bags were put into the rumen through the fistula for dry matter (DM) and crude protein (CP) degradability determination of the two concentrates used in the experiment. The $\mathrm{pH}$ values, $\mathrm{NH}_{3}$ and volatile fatty acids (VFA) concentration, and the number of protozoa were determined in rumen liquid samples. $\mathrm{NH}_{3}$ concentration was determined by the method of Kolb and Kamyshnikov (1982), while concentrate degradability according to Mehrez and Ørskov (1977) method with dacron bags of pore size $45 \mu \mathrm{m}$, and incubation time of $24 \mathrm{~h}$. The $\mathrm{pH}$ of rumen fluid was determined immediately after withdrawing the samples, with a $\mathrm{pH}$-meter (ORION, SA 720, Boston, USA). The VFA concentration and the chemical composition of forages, concentrates and faeces samples were determined as described by Zervas et al. (1999).

The energy content of the whole diets, in Net Energy of Lactation $\left(\mathrm{NE}_{\mathrm{L}}\right)$, was calculated according to Van Es (1978) and Schiemann et al. (1972) equations. Statistical analysis of the results was done according to Steel and Torrrie (1960), at the significance level of $\mathrm{P}<0.05$ according to the following linear model:

$$
\mathrm{Y}_{\mathrm{ijk}}=\mu+\mathrm{E}_{\mathrm{i}}+\mathrm{e}_{\mathrm{ijk}}
$$

where $Y_{i j}=$ the observation of $j$ sheep of $i$ treatment

$\mu=$ the overall mean

$\mathrm{E}_{\mathrm{i}}=$ the fixed effect of $\mathrm{i}$ treatment and

$\mathrm{e}_{\mathrm{ijk}}=$ experimental error $\left(0, \sigma^{2}\right)$

\section{RESULTS}

The chemical composition of the forages and concentrates is given in Table 2 . The chemical composition of the consumed diets is given in Table 3 which didn't differ among treatments, except for EE content which was $5.1 \%$ and $1.7 \%$ for the diets with (FC) and without (CC) fat, respectively. NDF concentration was about $42 \%$ in both diets (treatments) and ADF concentration almost similar and rather high $(\sim 27 \%)$ for both diets.

The inclusion of fat to the $\mathrm{FC}$ diet had no significant effect on nutrients apparent digestibility coefficients, except of that of $\mathrm{EE}$ which was significantly $(\mathrm{P}<0.001)$ higher in FC group, compared to the $\mathrm{CC}$ diet (Table 4). However, the energy content of the diet with fat (FC) was increased by $3.4 \%$ compared to the control (CC) diet $(\mathrm{P}<0.05)$. Ruminal $\mathrm{pH}$, ammonia concentration and concentrate $\mathrm{DM}$ degradability were not affected by fat inclusion (Table 5), while CP degradability increased 
TABLE 2

Chemical composition of feed

\begin{tabular}{lrrrr}
\hline Nutrients & $\mathrm{CC}^{\prime}$ & $\mathrm{FC}^{2}$ & Lucerne hay & Wheat straw \\
\hline Dry matter, g/kg & 878.8 & 897.4 & 897.2 & 899.9 \\
& & \multicolumn{2}{c}{$\mathrm{g} / \mathrm{kg} \mathrm{DM}$} & \\
Organic matter & 938.6 & 917.2 & 894.8 & 891.9 \\
Crude protein & 166.4 & 159.0 & 180.5 & 47.9 \\
Ether extract & 22.4 & 86.1 & 11.5 & 8.4 \\
Crude fibre & 88.0 & 82.4 & 309.3 & 452.4 \\
N-free extractives & 661.8 & 589.7 & 393.2 & 383.2 \\
NDF & 251.3 & 237.9 & 467.7 & 847.1 \\
ADF & 123.1 & 119.7 & 377.0 & 510.4 \\
Lignin + coutin & 40.1 & 46.2 & 99.2 & 68.4 \\
\hline
\end{tabular}

$1 \mathrm{CC}$ : control concentrate

${ }^{2} \mathrm{FC}$ : concentrate with fat

TABLE 3

Chemical composition of the ingested diets

\begin{tabular}{|c|c|c|}
\hline \multirow{2}{*}{ Nutrients } & \multicolumn{2}{|c|}{ Treatments } \\
\hline & $\mathrm{CC}^{\prime}$ & $\mathrm{FC}^{2}$ \\
\hline Dry matter, g/kg & 889 & 899 \\
\hline & \multicolumn{2}{|c|}{$\mathrm{g} / \mathrm{kg} \mathrm{DM}$} \\
\hline Organic matter & 917 & 906 \\
\hline Crude protein & 148 & 145 \\
\hline Ether extract & 17 & 51 \\
\hline Crude fibre & 221 & 216 \\
\hline $\mathrm{N}$-free extractives & 531 & 494 \\
\hline NDF & 424 & 415 \\
\hline $\mathrm{ADF}$ & 269 & 266 \\
\hline Lignin + coutin & 63 & 66 \\
\hline
\end{tabular}

I CC: control concentrate

2 FC: concentrate with fat

significantly $(\mathrm{P}<0.001)$ by $4 \%$. Protozoa counts in the ruminal liquid were reduced $(\mathrm{P}<0.001)$ by $32 \%$ in the diet with fat. Total VFA's concentration and molar proportion of acetate didn't differ among treatments (Table 6 ), while the molar proportion of propionate increased $(\mathrm{P}<0.05)$ by $10.7 \%$, and the molar proportion of butyrate decreased $(\mathrm{P}<0.05)$ by $6.1 \%$. Finally the acetate to propionate ratio decreased $(\mathrm{P}<0.01)$ by $13.2 \%$ for the diet with fat. 
TABLE 4

Apparent digestibility cocfficients of nutrients and diet energy content, $\%$

\begin{tabular}{|c|c|c|c|c|}
\hline & \multicolumn{2}{|c|}{ Treatments } & \multirow{2}{*}{ SEM } & \multirow{2}{*}{ Significance level ${ }^{3}$} \\
\hline & $\mathrm{CC}^{\prime}$ & $\mathrm{FC}^{2}$ & & \\
\hline Dry matter & 71.66 & 70.90 & 0.798 & NS \\
\hline Organic matter & 74.79 & 73.58 & 0.672 & NS \\
\hline Crude protein & 80.18 & 81.37 & 0.683 & NS \\
\hline Ether extract & 82.31 & 93.06 & 1.486 & $* * *$ \\
\hline Crude fibre & 52.12 & 49.26 & 1.360 & NS \\
\hline $\mathrm{N}$-free extractives & 81.94 & 80.40 & 0.602 & NS \\
\hline $\mathrm{NDF}$ & 58.83 & 57.93 & 1.050 & NS \\
\hline $\mathrm{ADF}$ & 52.99 & 54.60 & 1.197 & NS \\
\hline $\mathrm{NEL}, \mathrm{MJ} / \mathrm{kg} \mathrm{DM}$ & 6.54 & 6.76 & 0.057 & $*$ \\
\hline
\end{tabular}

${ }^{1} \mathrm{CC}$ : control concentrate

2 FC: concentrate with fat

$3 * * * \mathrm{P}<0.001, * \mathrm{P}<0.05$, NS: not significant

TABLE 5 Mean concentrate $\mathrm{DM}$ and $\mathrm{CP}$ degradability, $\mathrm{pH}$ values, $\mathrm{NH}_{3}$ concentration and protozoa counts in rumen liquid samples of sheep

\begin{tabular}{lccccc}
\hline & \multicolumn{2}{c}{ Treatments } & & \multirow{2}{*}{ SEM } & Significance lcvel $^{3}$ \\
\cline { 2 - 3 } & \multicolumn{1}{c}{$\mathrm{CC}^{\prime}$} & $\mathrm{FC}^{2}$ & & \\
\hline DM degradability, \% & 81.60 & 81.09 & .456 & $\mathrm{NS}$ \\
$\mathrm{CP}$ degradability, \% & $84.42^{\mathrm{a}}$ & $87.79^{\mathrm{b}}$ & .556 & $* * *$ \\
$\mathrm{pH}$ & 6.47 & 6.22 & .068 & $\mathrm{NS}$ \\
$\mathrm{NH}_{3}$ concentration, $\mathrm{mg} / \mathrm{dl}$ & 24.65 & 23.75 & 1.480 & $\mathrm{NS}$ \\
Protozoa counts $\mathrm{x}, 10^{5} / \mathrm{ml}$ & 6.34 & 4.31 & .290 & $* * *$ \\
\hline
\end{tabular}

$1 \mathrm{CC}$ : control concentrate

2 FC: concentrate with fat

$3 * * * \mathrm{P}<0.001$, NS: not significant

\section{DISCUSSION}

The lack of effect of added fat on nutrients apparent digestibility coefficients (Table 4) may be due to relatively high level of dietary ADF $(27 \%)$, that may reversed the negative effect of fat (Palmquist and Conrad, 1978; Palmquist and Jenkins, 1980), or to the fact that fat concentration was not high enough and the fat itself was saturated (Palmquist and Jenkins, 1980; Moore et al., 1986). However, in the present study, the lack of significant difference in DM degradation (Table 5), in total VFA concentration and in molar proportion of acetate (Table 6) are 
TABLE 6

Mean volatile fatty acids (VFAs) concentration in rumen liquid, \%

\begin{tabular}{|c|c|c|c|c|}
\hline & \multicolumn{2}{|c|}{ Treatments } & \multirow{2}{*}{ SEM } & \multirow{2}{*}{ Significance level } \\
\hline & $\mathrm{CC}^{\prime}$ & $\mathrm{FC}^{2}$ & & \\
\hline \multirow[t]{2}{*}{ Total VFAs } & 73.93 & 70.96 & 3.79 & NS \\
\hline & \multicolumn{4}{|c|}{ molar proportion, $\%$} \\
\hline Acetate & 61.28 & 60.97 & .413 & NS \\
\hline Propionate & 20.18 & 22.34 & .398 & $*$ \\
\hline Isobutyrate & 2.24 & 1.52 & .077 & $* * *$ \\
\hline Butyrate & 12.51 & 11.75 & .270 & $*$ \\
\hline Isovaleric & 2.02 & 1.63 & .084 & $* *$ \\
\hline Valeric & 1.50 & 1.79 & .079 & NS \\
\hline Acetic:propionic & 3.10 & 2.69 & .071 & $* *$ \\
\hline
\end{tabular}

I CC: control concentrate

${ }^{2} \mathrm{FC}$ : concentrate with fat

$* * * \mathrm{P}<0.001,{ }^{* *} \mathrm{P}<0.01,{ }^{*} \mathrm{P}<0.05, \mathrm{NS}$ : not significant

indications for absence of disturbance in rumen fermentation process. Therefore, it seems that the low feeding level (maintenance) and the starch replacement by fat on a weight basis and at a low level are the two major reasons for non significant differences in nutrient digestibility coefficients.

The increased ether extract (EE) digestibility for the diet with fat is in general agreement with the results of Palmquist and Conrad (1980), Jenkins and Palmquist (1984) and Moore et al. (1986), who used animal fat in rations of dairy cows and stecrs. The addition of animal fat in ruminant diet generally increases EE digestibility (Palmquist, 1984), depending on reduced ratio of non digestible lipids in the diet, or reduced ratio of endogenous lipids in the faeces (Palmquist and Conrad, 1978; Elliott et al., 1993).

The increased energy content $\left(\mathrm{NE}_{\mathrm{L}}\right)$ of the diet, when an amount of maize (a feed with high energy density) was replaced by the same amount of animal fat (Table 4), provides evidence that cereal grains could be replaced by fat in sheep diet without any adverse effects on the animals.

The addition of animal fat in the diet had no significant effect on DM degradability (Table 5) which can be explained by the arguments reported previously for digestibility coefficients. The absence of effect on DM degradability perhaps is also due to high ratio of saturated fatty acids in animal fat, which have smaller negative effect than unsaturated fatty acids (Palmquist and Jenkins, 1980). The increased CP degradability could be attributed to the declined counts of protozoa (Ushida et al., 1991), to the modification of bacterial population and to their in- 
creased activity, or mainly to the reduced contribution of low degradability maize protein to FC concentrate protein. Similar results were found by Goulas (2000) who also used animal fat. On the contrary, Weisbjerg et al. (1992) added animal fat in cows' diets and he found unaffected CP degradability.

Supplementation of diet with fat didn't affect significantly ruminal pH (Table 5 ) and this is in agreement to the lack of difference in total VFA concentration (Table 6). Grummer et al. (1993) found a decline in ruminal $\mathrm{pH}$, but also an increased concentration of VFA. Such a decline in $\mathrm{pH}$ was apparent also in this work, but it was not significant. The decrease of protozoa count in the present study may be due to the negative effect of fat on protozoa survival. Similar results were reported by Czerkawski (1973) and Ikwuegbu and Sutton (1982) who used vegetable oil, while Weisbjerg et al. (1992), who used tallow, found a declining trend on protozoa count.

The concentration of total VFA didn't differ among treatments (Table 6) and this is associated to the absence of differences in DM degradability between diet with or without fat (Table 5). Supplementation of diets with fat does not affect total VFA concentration (Palmquist and Conrad, 1980; Jenkins et al., 1998). However, Weisbjerg et al. (1992) found a significant decline in VFA concentration, while Grummer et al. (1993) found that the addition of tallow up to $3 \%$ in dairy cows' diet increased linearly total VFA concentration.

The molar proportion of acetate for the diet with fat didn't differ compared to the diet without fat, and that reflects the lack of disturbance of fibre fermentation in the rumen by the inclusion of animal fat (Kowalczyk et al., 1977; Weisbjerg et al., 1992; Elliott et al., 1993,1997; Bertrand and Gimes, 1997). Increased molar proportion of propionate and decreased acetate to propionate ratio were found by Kowalczyk et al. (1977), Weisbjerg et al. (1992), Bertrand and Gimes (1997) and Elliott et al. (1997) who added animal fat to dairy cows' diets. Finally, the significant reduction of molar proportion of butyrate is in agreement to the results of Tackett et al. (1996) and Bertrand and Gimes (1997).

\section{CONCLUSIONS}

The unaffected nutrients apparent digestibility coefficients and DM degradability, indicated that animal fat didn't disturb the rumen fermentation process, while increased the energy content of the diet. Consequently, it could be concluded that the replacement of cereal grains by animal fat, is feasible up to $5 \%$ total fat concentration in sheep diets, particularly when the ADF content of the diet is relatively high. 


\section{REFERENCES}

Bertrand J.A., Grimes L.W., 1997. Influence of tallow and Aspergillus oryzae fermentation extract in dairy cattle rations. J. Dairy Sci. 80, 1179-1184

Clark J.H., Klusmeyer T.H., Cameron M.R., 1992. Microbial protein synthesis and flows of nitrogen fractions to the duodenum of dairy cows. J. Dairy Sci. 75, 2304-2323

Czerkawski J.W., 1973. Effect of linseed oil fatty acids and linseed oil on rumen fermentation in sheep. J. Agr. Sci. 81, 517-531

Donkin S.S., Varga G.A., Sweeney T.F., Muller L.D., 1989. Rumen-protected methionine and lysine: Effects on animal performance, milk protein yicld and physiological measures. J. Dairy Sci. 72, 1484-1491

Elliott J.P., Drackley J.K., Aldrich C.G., Merchen, N.R., 1997. Effects of saturation and esterification of fat sources on site and extent of digestion in stecrs: Ruminal fermentation and digestion of organic matter, fiber, and nitrogen. J. Anim. Sci. 75, 2803-2812

Elliott J.P., Dracklcy J.K., Schauff D.J., Jaster E.H., 1993. Diets containing high oil corn and tallow for dairy cows during early lactation. J. Dairy Sci. 76, 775-789

Goulas C., 2000. The effect of dietary fat on sheep diet digestibility and on lactating ewes performance. Ph.D. Thesis, Agricultural Univiversity of Athens (Greece)

Grummer R.R., 1991. Effect of feed on the composition of milk fat. J. Dairy Sci. 74, 3244-3257

Grummer R.R., Luck M.L., Barmore J.A., 1993. Rumen fermentation and lactation performance of cows fed roasted soybeans and tallow. J. Dairy Sci. 76, 2674-2681

Hvelplund T., Madsen J., 1990. A study of the quantitative nitrogen metabolism in the gastrointestinal tract, and the resultant new protein evaluation system for ruminants. The AAT-PBV system.

D.Sc. Thesis, Royal Veterinary Agricultural Univiversity, Copenhagen (Denmark)

Ikwuegbu O.A., Sutton J.D., 1982. The effect of varying the amount of linseed oil supplemantation on rumen metabolism in sheep. Brit. J. Nutr. 48, 365-375

Jenkins T.C., Bertrand J.A., Bridges, W.C.Jr., 1998. Interactions of tallow and hay particle size on yield and composition of milk from lactating Holstein cows. J. Dairy Sci. 81, 1396-1402

Jenkins T.C., Palmquist D.L., 1984. Effect of fatty acids or calcium soaps on rumen and total nutrient digestibility of dairy rations. J. Dairy Sci. 67, 978-986

Kolb V.G., Kamyshnikov V.S., 1982. Clinical Chemistry (in Russian). Minsk, Belarus, pp. 31

Kowalczyk J., Ørskov E.R., Robinson J.J., Stewart C.S., 1977. Effect of fat supplementation on voluntary food intake and rumen metabolism in sheep. Brit. J. Nutr. 37, 251-257

Mchrez. A.Z., Orskov E.R., 1977. A study of the artificial fibre bag technique for determining the digestibility of feeds in the rumen. J. Agr. Sci. 88, 645-650

Moore J.A., Swingle R.S., Hale W.H., 1986. Effects of whole cottonseed, cottonseed oil or animal fat on digestibility of wheat straw diets by steers. J. Anim. Sci. 63, 1267-1273

Palmquist D.L., 1984. Use of fats in diets for lactating cows. In: J. Wiseman (Editor). Fats in Animal Nutrition. Butterworths, London, pp. 357-381

Palmquist D.L., Conrad H.R., 1978. High fat rations for dairy cows. Effects on feed intake, milk and fat production, and plasma metabolites. J. Dairy Sci. 61, 890-901

Palmquist D.L., Conrad H.R., 1980. High fat rations for dairy cows. Tallow and hydrolyzed blended fat at two intakes. J. Dairy Sci. 63, 391-395

Palmquist D.L., Jenkins T.C., 1980. Fat in lactation rations: Revicw. J. Dairy Sci. 63,1-14

Schiemann R., 1972. Energetische Futterbewertung und Energienormen. VED Deut. Landwverlag, Berlin

Stcel R.G.D., Torric J.H., 1960. Principles and Procedures of Statistics. McGraw-Hill Book Company, Inc. 
Stern M.D., Varga G.A., Clark J.H., Firkins J.L., Huber J.T., Palmquist D.L., I994. Evaluation of chemical and physical properties of feeds that affect protein metabolism in the rumen. J. Dairy Sci. $77,2762-2786$

Tackett V.L., Bertrand J.A., Jenkins T.C., Pardue F.E., Grimes L.W., 1996. Interaction of dietary fat and acid detergent fiber diets of lactating dairy cows. J. Dairy Sci. 79, 270-275

Ushida K., Jouany J.P., Demeyer D., 1991. Effects of presence or absence of rumen protozoa on the efficiency of utilization of concentrate and fibrous feeds. In: Physiological Aspects of Digestion and Metabolism in Ruminants. Proceedings of the 7 th International Symposium on Ruminant Physiology. Academic Press, Inc., pp. 625-654

Van Es A.J.H., 1978. Feed evaluation for ruminants. Livest. Prod. Sci, 5, 331-345

Weisbjerg M.R., Borsting C.F., Hvelplund T., 1992. The influence of tallow on rumen metabolism, microbal biomass synthesis and fatty acid composition of bacteria and protozoa. Acta Agr. Scand., Anim. Sci. 42, 138-147

Zervas G., Zarkadas L., Goulas C., Mantzios A., 1999. The effect of altering the hay to concentrate ratio and concentrate composition on the rumen fermentation of dry sheep and milk production of lactating dairy ewes. Anim. Sci. 79, 270-275

\section{STRESZCZENIE}

\section{Wplyw dodatku tluszezu zwierzęcego na strawność składników pokarmowych dawki, degra- dację bialka i procesy fermentacyjne w żwaczu}

Badano wpływ zastąpienia ziarna kukurydzy tłuszczem zwierzęcym w dawce $\mathrm{z}$ wysoką zawartością ADF $(27 \%)$ na strawność składników pokarmowych, przebieg fermentacji w żwaczu oraz wartość encrgetyczną dawki. Doświadezenie przeprowadzono na 6 przetokowanych skopach w układzie kwadratu lacińskiego $2 \times 2$. Stosunek paszy objętościowej do treściwej w dawkach wynosił 47,7:52,3; udział tłuszczu zwierzęcego stanowił 7\% paszy treściwej, zastępując wagowo ziarno kukurydzy.

Strawność ekstraktu eterowego dawki z tłuszczem zwiększyła się $(P<0,001)$ o 13,1\% w porównaniu z kontrolną, podczas gdy strawność pozostałych składników pokarmowych nie różniła się. Wartość cnergetyczna dawki z dodatkiem tłuszczu zwiększyła się o 3,4\% (P<0,05) w porównaniu $z$ kontrolną. Przy skarmianiu dawki z udziałem thuszczu zwierzęcego istotnie zwiększył się $(P<0,05)$ molarny udział propionianów, o $10,7 \%$, oraz rozkład białka ogólnego o 4\% (P<0,001), a obniżył się molarny udział maślanów o $6,1 \%(\mathrm{P}<0,05)$, stosunek octanów do propionianów o $13,2 \%(\mathrm{P}<0,001)$ oraz liczba pierwotniaków o $32 \%(\mathrm{P}<0,001)$.

Otrzymane wyniki wskazują, że tłuszczem zwierzęcym można częściowo (do 5\%) zastạpić ziarno zbóż w dawkach dla owiec bez zakłócenia przebiegu fermentacji w żwaczu. 